\title{
EL SURGIMIENTO DE LA EDUCACIÓN EN EMPRENDEDURISMO PERIODÍSTICOY UN EJEMPLO DE CASO DE ESTUDIO COMO HERRAMIENTA DOCENTE
}

\author{
María José Vázquez-Schaich ${ }^{1}$ : Universidad de Navarra. España \\ mvazquezs@alumni.unav.es
}

\section{RESUMEN}

Las facultades de comunicación no han permanecido ajenas al intenso proceso de cambio y experimentación que vive la industria de los medios. En esta comunicación se analiza la tendencia en estas instituciones a acentuar la formación en la economía y el negocio de los medios, así como en habilidades de gestión, marketing, innovación $\mathrm{y}$, especialmente, en emprendedurismo. A través del emprendedurismo las facultades pretenden formar periodistas que ante la destrucción de puestos laborales, la transformación de los modelos de negocio y la destrucción de valor en las empresas de la industria, sepan aprovechar las herramientas del entorno digital para encontrar y explotar oportunidades: crear organizaciones nuevas y trabajar por su propia cuenta; trabajar en instituciones en transformación, que exigirán esas habilidades a sus periodistas; y, en cualquiera de los dos casos, que entiendan cómo crear valor para las audiencias y puedan aportar, a través de la experimentación y la innovación, a la sostenibilidad del periodismo y el desarrollo de la industria. En la segunda parte de este artículo se presenta un caso de estudio que se realizó en 2010 en Estados Unidos como primer ejemplo de un proyecto del Center of Communication Leadership and Policy para producir material docente para este tipo de asignaturas.

PALABRAS CLAVE: Periodismo - Emprendedurismo - Educación Comunicación - Caso

\footnotetext{
${ }^{1}$ Autor Correspondiente

María José Vázquez-Schaich ${ }^{1}$ : Profesor de la Universidad de Navarra. España.

Correo: $\underline{\text { mvazquezs@alumni.unav.es }}$
} 


\section{THE RISE OF ENTREPRENEURIAL JOURNALISM EDUCATION AND A SAMPLE CASE STUDY FOR TEACHING}

The media industry is undergoing one of the most intensive period of experimentation in its history, and so too are journalism schools. This paper examines the trend in journalism schools towards transforming their curricula to emphasize business, management and especially entrepreneurship skills. Offering entrepreneurial skills, jschools seek to train journalists who can take advantage of the new digital environment and the digital tools to find and exploit opportunities: who can create new journalism organizations and work on their own; who can work in transforming organizations that will require these kind of skills to their journalists; and in both cases, professionals who understand how to create value for their audiences and contribute to the development and sustainability of journalism through innovation and experimentation. The second part of this paper presents a case study developed in 2010 in United States as part of a project of the Center of Communication Leadership and Policy to produce teaching resources for entrepreneurial journalism courses.

KEY WORDS: Journalism - Entrepreneurship - Education - Communication - Case

\section{INTRODUCCIÓN}

\subsection{Innovación en Facultades de Comunicación y Periodismo Emprendedor}

La industria de los medios atraviesa el período de transformación y experimentación más intenso de su historia. El proceso de declive del modelo de medios masivos antecede a la aparición de internet, y responde a los cambios sociales y en el estilo de vida de los individuos, a los cambios económicos y tecnológicos, y a la consecuente fragmentación de las audiencias y anunciantes (Picard, 2010). Sin embargo, las tecnologías digitales en consonancia con la conexión en red, causaron un efecto disruptivo, un punto de inflexión para la industria, que ha motivado un replanteamiento obligado por parte de todas las instituciones del ecosistema de medios: empresas de comunicación, organismos regulatorios e instituciones educativas.

El modelo de negocio de los medios masivos se sustentó por más de cincuenta años en unas estructuras de mercado oligopólicas e incluso monopólicas, es decir, en lo

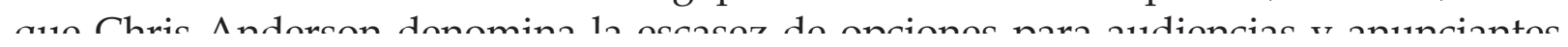


Al mismo tiempo, frente al déficit de periodismo de calidad que plantea la transformación de la industria (debido a los recortes de plantillas y operaciones), surgió una verdadera explosión de experimentos y emprendimientos en periodismo e información digital: iniciativas con y sin fines de lucro, fundadaspor emprendedores, medios, instituciones o fundaciones, que intentan, no sin dificultades, reconstruir un ecosistema que garantice la sostenibilidad del periodismo. (Kaye \& Quinn, 2010); (Grueskin, Seave \& Graves, 2011).

Las facultades de periodismo no permanecieron ajenas a este proceso. Por un lado, replantean sus ofertas formativas; los planes de estudio tradicionalmente se orientaron a formar profesionales para ocupar unos puestos laborales que responden al "paradigma de la redacción"(Anderson et al., 2011, p.7); (Glaser, 2008), es decir, a las estructuras y la lógica de un sistema de medios que está en declive. Hoy, las facultades asumen que el periodista aún cumple un rol esencial en la sociedad y en el sistema democrático, pero entienden que éste debe adaptarse al nuevo entorno, incorporar habilidades para conectar con los individuos y las comunidades e internalizar la concepción de creación de valor en su trabajo.

Por otro lado, un reciente informe de Anderson et al., muestra el esfuerzo de las facultades de periodismo en Estados Unidos por abandonar un rol pasivo en la industria (Anderson et al., 2011) y por posicionarse como incubadoras de emprendedurismo y a participar activamente en el proceso de experimentación en nuevos modelos que sustenten al periodismo (OGUNTOYINBO, 2010).

De acuerdo al informe de Anderson y colaboradores, existe una tendencia en las facultades de periodismo en Estados Unidos a adoptar sistemas comparables a los de la formación de médicos internos residentes de medicina. Los autores lo explican de la siguiente forma:

Así como los hospitales no sólo dictan clase a sus alumnos, sino que también les integran en la atención de pacientes y en proyectos de investigación, los programas en periodismo no deben limitarse a dar clase a los alumnos, sino que, junto con ellos, también deben hacer periodismo para sus comunidades y convertirse en laboratorios de innovación para la industria. Deben testear nuevos modelos para el periodismo, comprender cómo emergen los ecosistemas periodísticos y, al mismo tiempo, contribuir en la creación de las políticas públicas que los soportan (Anderson et al., 2011, p.1-2). 
En este sentido, las facultades de periodismo crearon múltiples iniciativas en colaboración con medios de comunicación, emprendedores periodísticos digitales y fundaciones filantrópicas: programas en los que profesores, alumnos y profesionales participan en la generación sistemática de contenidos para sus comunidades y experimentan con nuevos enfoques y prácticas en periodismo digital; programas de investigación, innovación y testeo de nuevos modelos de negocio; programas de formación a emprendedores; programas de incubación y financiación de emprendimientos periodísticos digitales; y programas para investigar y documentar la evolución de los nuevos modelos y la actividad emprendedora (buenas prácticas, fallos, obstáculos, etc.).

Sin ánimo de ser exhaustivos, haremos referencia a algunos ejemplos representativos de estos programas. Entre los numerosos proyectos de universidades testeando modelos y aportando a la industria y sus comunidades a través de la puesta en marcha de medios digitales, se puede citar como ejemplo Reporting Texas, un sitio de periodismo multimedia local fundado por profesores y alumnos de la Universidad de

Texas en Austin. Reporting Texas cubre asuntos que no abarcan los medios locales y pone los contenidos a disposición de cualquier medio para su reproducción gratuita. Los objetivos del proyecto son: “Exponer el trabajo de los alumnos de grado y posgrado de la Universidad de Texas; ofrecer una cobertura multimedia de calidad para medios locales, estatales y nacionales; experimentar en nuevas fórmulas para la educación en periodismo; y combinar aspectos de la cobertura de temas comunitarios con recursos multimedia" 2 .

Tres proyectos similares lanzó Annenberg School of Communication de la Universidad de Southern California para cubrir distintas comunidades geográficas y culturales. Por ejemplo, en Alhambra Source periodistas, investigadores de Annenberg, desarrolladores web y alumnos cubren asuntos relevantes y llevan adelante un calendario de eventos para esa comunidad. Además, dadas las características demográficas de esta comunidad de las afueras de Los Ángeles, todos los contenidos se traducen al español y al mandarín. Intersections es un sitio de noticias comunitarias que pretende ser una "fuente de información independiente para los comunidades de los alrededores del campus, al mismo tiempo que un espacio de entrenamiento en emprendedeurismo y periodismo para los estudiantes" ${ }^{3}$. 
Otro ejemplo en este sentido es el de New York Times, que estableció un acuerdo con el programa Studio 20 de New York University y con City University of New York (CUNY) a través del cual profesores y alumnos llevan adelante sitios de información hiper local de New York Times. También Studio 20 y Propublica.org, la primera organización digital sin fines de lucro en ganar un premio Pulitzer, investigan la aplicación de herramientas multimedia para potenciar el periodismo explicativo en el entorno digital ${ }^{4}$.

Por su parte, la facultad de periodismo de la Universidad de Berkeley también gestiona tres sitios de información hiper local en comunidades que, según sus fundadores, sufren un déficit informativo. Recientemente, la facultad contrató al emprendedor en periodismo digital David Cohn, fundador de Spot.Us, una plataforma sin fines de lucro de financiación colectiva de proyectos de investigación periodística, para apoyar a los alumnos en la gestión de los tres proyectos de periodismo hiper local, investigar en nuevos modelos de negocio para el periodismo y dictar algunos cursos y seminarios.

En la formación de profesionales y emprendedores, y en la financiación y testeo de nuevos modelos se puede citar, por ejemplo, el Knight News Innovation Lab de la Universidad de Northwestern, que tiene como objetivo acelerar el desarrollo del periodismo digital en Chicago a través del desarrollo de proyectos con distintos medios. J-Lab es un programa de la American University que actúa como incubadora de startups en periodismo, otorga premios a la innovación, realiza consultorías a medios y universidades, desarrolla módulos de aprendizaje en periodismo multimedia y emprendedurismo, y ofrece cursos de formación a emprendedores y profesionales del periodismo. Como explican en su web, a través de estas iniciativas, "crean espacios de experimentación, identifican qué funciona y aplican esos insights al futuro del periodismo" 5 .

Tow-Knight Center for Entrepreneurial Journalism es un centro de CUNY que gestiona un programa de posgrado en emprendedurismo en periodismo, financia la creación de startups periodísticos e investiga y desarrolla prototipos en nuevos modelos de negocio para el periodismo ${ }^{6}$. El Knight Digital Media Center es una iniciativa de dos universidades, University of Southern California y la Universidad de Berkley. El centro otorga becas a periodistas y emprendedores para asistir a diversos campamentos de formación intensiva en herramientas multimedia, emprendedurismo y liderazgo y, al mismo tiempo, actúa como incubadora de nuevos emprendimientos y ofrece en sus webs tutoriales y recursos para profesionales.

4 En este vídeo el director de Studio 20, Jay Rosen, explica los objetivos del programa: 
Arizona State University fundó el Knight Center for Digital Media Entrepreneurship. El centro ofrece formación en emprendedurismo y periodismo a estudiantes de periodismo, gestión de empresas, ingeniería informática y diseño. Al mismo tiempo, los alumnos trabajan con emprendedores digitales asociados en proyectos individuales para lanzar su propio medio o servicio digital.

La Universidad de Missouri, a través del Reynolds Journalism Institute trabaja en diversos proyectos de investigación, experimentación y formación en nuevos modelos de negocio y emprendedurismo. Por ejemplo, coordina el RJI Collaboratory, una red de académicos en la que estudiantes, expertos de marketing, publicidad y tecnología, periodistas y emprendedores comparten experiencias en la creación de proyectos y servicios periodísticos de nicho en el entorno digital. La red también ofrece todo tipo de recursos (seminarios, módulos y herramientas) para todos los emprendedores miembros. Reynolds Institute también gestiona Block by Block, que estudia el movimiento emprendedor en periodismo comunitario y organiza una conferencia anual para que los emprendedores compartan sus experiencias.

Otro ejemplo de innovación son los programas de en desarrollo y programación web para periodismo de las universidades de Northwestern, Columbia y Georgia Tech. Estos cursos tienen el objetivo de cubrir la demanda de este perfil profesional en la industria, así como formar profesionales y periodistas que emprenden nuevas organizaciones y trabajen por su cuenta en el entorno digital.

En prácticamente todos los casos comentados, los académicos y profesionales asociados a los distintos centros investigan y documentan la evolución del ecosistema de medios y las lecciones aprendidas en sus distintos programas para luego distribuir ese aprendizaje con otras universidades, medios y emprendedores.

Este último punto es quizá uno de los más relevantes en un contexto de plena experimentación y de incertidumbre en cuanto a los modelos de negocio que funcionarán. La investigación y la documentación del proceso emprendedor permite que medios, profesionales y universidades aprendan día a día de las experiencias y experimentos de sus pares $y$, hoy más que nunca, están compartiendo esa experiencia a través de diversos canales: actividades, conferencias e investigación de las universidades, conferencias profesionales, y también a través de los medios sociales y blogs. 
Esto también tiene ver con que en el entorno digital los medios y emprendedores trabajan cada vez más en redes y en colaboración. Entienden que no pueden hacer todo lo que hacían antes en el entorno físico de la escasez y, por eso, establecen redes para distribuir sus contenidos, para cubrir determinados temas, para establecer sinergias, por ejemplo, en la venta de publicidad, o para innovar y experimentar con nuevos productos ${ }^{7}$.

Es relevante también mencionar que, en Estados Unidos, la actividad filantrópica tiene un rol fundamental en el desarrollo de los distintos programas de innovación en las universidades. La gran mayoría de los proyectos que citamos cuenta con la colaboración de distintas fundaciones. Knight Foundation es una de las instituciones más comprometidas en la financiación de proyectos para promover la innovación y experimentación en periodismo. En la web de la fundación figuran 356 proyectos de innovación, financiación e incubación de proyectos periodísticos, apoyo a programas de innovación en facultades de periodismo, desarrollo de herramientas digitales y software de código abierto para promover la integración de este tipo de herramientas en organizaciones de medios y en proyectos emprendedores, y programas de formación, investigación y documentación de la evolución de la industria.

La mayoría de esos proyectos se organizan en colaboración con universidades, fundaciones e instituciones locales, e incluso financian iniciativas de particulares. También participan activamente en la financiación de este tipo proyectos otras fundaciones reconocidas como Ford Foundation, Carnegie Foundation, McCormick Foundation, y diversas fundaciones locales que comienzan a aportar fondos para promover el desarrollo del periodismo en sus comunidades (Switzer, 2011).

En cuanto a la reformulación de los planes de estudio, y teniendo en cuenta lo descrito hasta ahora, no sorprende que una de las tendencias más importantes, aparte de la integración de herramientas y habilidades multimedia, pase por acentuar la formación en la economía y el negocio de los medios, así como en habilidades de gestión, marketing, innovación y, especialmente, en emprendedurismo (Glaser, 2008).

Existe un amplio consensoentre académicos y reguladores en que el emprendedurismo es una de las claves del desarrollo económico y del bienestar social; a través de la búsqueda y la explotación de oportunidades (Shane \& Venkataraman, 2000, p. 217-226) los emprendedores crean puestos laborales, promueven la innovación y aceleran los cambios estructurales de la economía (Kelley, Bosma \& Amorós, 2011). 
En este sentido, al integrar estas habilidades en la formación de sus alumnos, las facultades persiguen el objetivo de formar periodistas que ante la destrucción de puestos laborales, la transformación de los modelos de negocio y la destrucción de valor en las empresas de la industria, sepan aprovechar las herramientas del entorno digital para encontrar y explotar oportunidades: crear organizaciones nuevas y trabajar por su propia cuenta; trabajar en instituciones en transformación, que exigirán esas habilidades a sus periodistas; $y$, en cualquiera de los dos casos, que entiendan cómo crear valor para las audiencias y puedan aportar, a través de la experimentación y la innovación, a la sostenibilidad del periodismo y el desarrollo de la industria.

Para John Harris, editor y fundador de Politico.com, se trata de que los periodistas actúen dentro o fuera de las organizaciones tradicionales "como creadores de valor individuales". Y continúa: "Los periodistas son una franquicia... [Deben preguntarse] ¿Qué valor crean y qué tan transferible es ese valor (The Paley Center for Media, 2010)?

Pero este enfoque exige cambiar algunas concepciones arraigadas en la actividad periodística. En este sentido, un sector cada vez más amplio de representantes de la academia y la industria coinciden en la necesidad de derribar las murallas que durante tantos años se establecieron entre la gestión y la redacción de la empresa periodística. "Los periodistas deben tener más responsabilidad en el futuro de sus empresas"8 (Benkoil, 2010), explica Stephen Shepard, director del instituto de posgrado en periodismo de City University of New York (CUNY).

De la misma forma, en un controvertido discurso en la conferencia News:rewired en 2010, Marc Reeves, periodista con 15 años de experiencia en periódicos regionales de Reino Unido y actual editor del startup The Business Desk, expresó que esta división "artificial" entre redacción y gestión resultó "uno de los errores más graves que cometieron los medios" (Slattery, 2011). A la misma conclusión llegaron también representantes de la academia y la industria en una mesa redonda en emprendedurismo y periodismo en la Carnegie Educators Summit, moderada por Jeff Jarvis, periodista y director de programa de periodismo y emprendedurismo de CUNY. En esta instancia, Geneva Overholser, prestigiosa periodista y editora que trabajara medios como Washington Post y New York Times, y actual directora de Annenberg School of Communication en University of Southern California, explicó que esta división provocó que los periodistas se desentendieran de las necesidades de las audiencias y, por lo tanto, afectara también su función social en la integración de comunidades (The Paley Center for Media, 2010): 
El hecho de que no nos preocupáramos de las audiencias tuvo efectos negativos sobre nosotros. Nos desentendimos de las audiencias. Uno de los aspectos más promisorios del nuevo entorno es que tendremos periodistas que tendrán que preocuparse por las audiencias, dónde están, cómo las van a alcanzar y también cómo van a sostener su actividad... (Hoy) nos convertimos en marketers, entendemos analítica web, entendemos de search engine oprtimization y entendemos cómo se sustentan diversas organizaciones de medios (The Paley Center for Media, 2010).

En respuesta, diversas facultades de comunicación integraron a sus programas en periodismo nuevos cursos en emprendedursimo (Anderson et. al., 2011; Jarvis, 2010; Benkoil, 2010) y reforzaron la formación en fundamentos de management y economía de los medios, a nivel de grado y posgrado. A principios de 2010 Jeff Jarvis organizó una videoconferencia con más de 25 profesores de distintas universidades que comienzan a integrar estos contenidos en las carreras de periodismo (Jarvis, 2010). Como comentó el periodista, los profesores asistentes valoraron la rápida expansión del emprendedurismo en las carreras de periodismo y asumieron que "fue irresponsable" por parte de las universidades haber obviado estos contenidos.

La descripción de los programas de los cursos de emprendedurismo que compartieron los profesores en el wiki entrepreneurialjourno.pbworks.com, en Poynter News University ${ }^{9}$ o en las webs de los distintos centros, muestran cierta heterogeneidad propia de esta etapa de experimentación, sin embargo, podemos comprobar que en la mayoría de los casos se utilizan herramientas similares a los cursos de emprendedurismo de las escuelas de negocios o facultades de administración y management (Collete, Hill, y Leitch, 2005, p. 98-111).

Es decir, generalmente cuentan con un componente teórico en asuntos que competen a la creación de empresas periodísticas en el entorno digital, estrategia, marketing y modelos de negocio; un componente práctico de desarrollo de proyectos y/o modelos de negocio para un producto o servicio periodístico; a la vez que se trabaja con el método del caso y con las sesiones con emprendedores que comparten sus experiencias de primera mano con los alumnos. Por esa razón, las actividades de las facultades en el apoyo a la industria y a los emprendedores que mencionamos anteriormente, la participación en diversos experimentos, la incubación de startups y la documentación de los avances, aciertos y errores, son fundamentales para complementar la formación de los alumnos. Más aún, en el contexto actual en el que, aunque apoyados en las instituciones educativas y fundaciones, en definitiva, son los emprendedores y medios los principales agentes de experimentación, y los que moldearán el nuevo ecosistema de medios. 
En la videoconferencia de profesores de emprendedurismo y periodismo a la que hicimos referencia, éstos pusieron especial énfasis en la necesidad de construir una base de casos de estudio como herramienta docente (McFadden, 2009). Algunos profesores comienzan a desarrollar sus propios casos en torno a la experiencia de emprendedores del periodismo digital y utilizan casos disponibles del área de management, emprendedurismo y creación de empresas y startups de las escuelas de negocios. Sin embargo, como sucede en la investigación y docencia en las áreas de Gestión de Empresas de Comunicación y Economía de los Medios, es preciso desarrollar materiales propios, para así "crear un puente entre la disciplina general y las especificidades de la industria y organizaciones de medios" (Küng, 2007, pp. 2139).

A través del método del caso, los alumnos se acercan a las experiencias de los profesionales y emprendedores en el mundo real, pero a diferencia de las sesiones con profesionales, esta herramienta permite que el profesor focalice los objetivos de la sesión y la atención de la clase en determinados aspectos de la experiencia. Al mismo tiempo, el caso de estudio es una herramienta docente que permite enseñar a los alumnos habilidades propias del emprendedurismo y el management. Como explica David Garvin, la discusión de casos cumple tres funciones: ayuda a los alumnos a desarrollar habilidades de diagnóstico en escenarios de cambio constante de los mercados y la tecnología; promueve el desarrollo de habilidades persuasivas, necesarias para trabajar e interactuar con el equipo y el resto de agentes con los que se relaciona una organización; y, por último, obliga a los alumnos a desarrollar distintas formas de pensar y actuar, y entrena en el hábito de tomar decisiones (Garvin, 2003, p .56-65).

El caso que presentamos es el primer resultado de un proyecto de losautores en el Center of Communication Leadership and Policy de Annenberg School of Communication de la University of Southern California, que pretende aportar en la creación de una base de datos de casos en emprendedurismo y periodismo.

El objetivo de este caso en concreto es que los alumnos puedan discutir y comprender la variedad de desafíos que enfrentan los emprendedores en el proceso de crear un proyecto periodístico y de establecer un modelo de negocio en el entorno digital. Se centra, específicamente, en las fases de creación y supervivencia de pequeñas empresas, y enfrenta a los estudiantes a situarse en el lugar de los emprendedores que, en determinado contexto, deben tomar decisiones para promover la sostenibilidad de su proyecto.

I os temas de discusión a11e nlantea el caso v la guía docente tienen s11 contranartida 
La investigación inició con una revisión bibliográfica en creación de empresas y emprendedurismo en el entorno digital. La vasta producción académica y divulgativa en estos campos permitió crear un marco de investigación general y reconocer puntos comunes a toda actividad emprendedora. Además, se consultaron diversas investigaciones (la mayoría de ellas surgen de los programas de las universidades y fundaciones que comentamos anteriormente, y que se citan en el caso) que documentan la actividad emprendedora en periodismo en Estados Unidos, y se asistió a dos campamentos de formación intensiva de emprendedores del periodismo: Knight Community Info Challenge Boot Camp $2010^{10}$ y el News Entrepreneur Boot Camp 2010 11.

Se trata de programas de la Knight Foundation y University of Southern California de financiación de emprendedores y entrenamiento intensivo enaspectos de creación, desarrollo y sostenibilidad de proyectos periodísticos en el entorno digital. Al mismo tiempo, estas instancias sirven de foros para que los emprendedores compartan experiencias y fórmulas, y discutan qué modelos y estrategias funcionan para cada uno y cuáles no, y qué dificultades han encontrado a la hora de fundar y viabilizar su actividad. En ambos programas, los autores tuvieron la oportunidad de escuchar diversas experiencias, así como mantener entrevistas con los distintos emprendedores.

La meta para este primer caso fue representar los desafíos y obstáculos más usuales que enfrentan los fundadores de sitios de periodismo local y tratar los asuntos clave con los que deben lidiar los emprendedores periodísticos en el entorno digital. Algunos desafíos recurrentes que se descubrieron en la investigación y que se plantean en el caso y en la guía para los docentes son:

a) La importancia del plantear objetivos y metas a alcanzar desde el inicio del proyecto, así como un plan de negocio, un examen detenido de los ingresos y costes. Si bien es cierto que la creación y gestión de empresas en el entorno digital se caracteriza por la flexibilidad, volatilidad y adaptabilidad, es preciso iniciar con una idea clara y medible de los objetivos. La investigación refleja que uno de los problemas recurrentes de las primeras etapas de actividad de los periodistas emprendedores radica en que éstos usualmente focalizan su atención excesivamente en el contenido y la tecnología y menos en el modelo de negocio y la gestión. Flexibilidad y adaptabilidad no implica falta de visión.

b) Cómo los fundadores distribuyen las múltiples tareas que implica emprender una empresa de esta naturaleza y de escala reducida.

c) Cuáles son los desafíos de plantear un modelo de negocio exclusivamente apovado en la publicidad para emprendimientos digitales de 
d) Qué valor crean este tipo de sitios a los anunciantes locales, qué problemas surgen y cuáles son los métodos adecuados a la hora de vender publicidad. Quién vende publicidad.

e) Qué tipo de fuentes de ingreso alternativas se pueden explotar. Qué tipo de colaboración y redes entablan los emprendedores para potenciar su escala y compartir recursos. Este punto se presenta en la guía docente como uno de los posibles temas sobre los que orientar la discusión de clase, y se ofrece material de referencia para preparar el tema.

f) Qué tipos de contenido logran comprometer, involucrar y crear valor para los usuarios.

g) Experiencias al integrar periodismo ciudadano en la producción de contenidos. Qué prácticas pueden promover la participación de los usuarios.

h) Cómo manejar los recursos escasos y cuáles son las posibles fuentes de financiación para este tipo de emprendimientos.

El caso fue utilizado por el profesor Jeffrey S. Klein en los cursos de Business of Media en Annenberg School of Communication y en Columbia Journalism School; y una versión del caso se distribuye a través de Columbia Case Studies Initiative, una iniciativa de Knight Foundation y Columbia Journalism School para promover el uso del caso de estudio en la enseñanza del periodismo y la comunicación ${ }^{12}$. También existe una versión interactiva del caso, que cuenta con vídeos de los protagonistas, gráficos y fotos de la evolución del proyecto. La guía docente está disponible para las dos versiones. Como ejemplo, aquí presentamos un extracto del caso:

\section{METODOLOGÍA}

La base metodológica de la presente investigación se sustenta en el empleo del método análitico-sintético, el cual facilita el análisis las tendencias en las instituciones de educación para acentuar la formación en la economía y el negocio de los medios, así como en habilidades de gestión, marketing, innovación y, especialmente, en emprendedurismo.

\section{ANÁLISIS Y DICUSIÓN}

\subsection{El caso. Long Beach Post Online Community News: A Case Study in Long Beach, California. What It Takes to Survive and Thrive}

A profound crisis is taking place in American journalism. Newspapers are closing their doors. Viewership of network and local television news broadcasts is a fraction 
that the important "watchdog" function of the press may further deteriorate or even disappear. However, in the face of these seemingly depressing facts, a vibrant new industry is being developed-online hyper-local community news. The industry is in its infancy, and it is too early to know whether community and specialized news websites can be a viable and sustainable solution that will fill the local journalism gap.

Print and television advertising has supported journalism for decades. This historical accident, of vast revenues and huge profits from advertising being used to pay for indepth professional journalism, is nearing an end. Whether using Google, Groupon or some other digital solution, advertisers can reach their audiences without paying to be adjacent to editorial content. "Signs that advertising, at least in any familiar form, would ever grow to levels sufficient to finance journalism online [are] ... in doubt" (Pew Project for Excellence in Journalism, 2010), according to one recent report. In the face of these changes, entrepreneurs across the nation are experimenting with new business models in journalism. In the last several years, thousands of community news sites have been launched in cities large and small. In 2006, one in eight U.S. residents was served by a community news website, or what Lisa Williams, the founder of placeblogger.com, calls a "place blog" By 2010, that number was one in two (Williams, 2010).

However, community news sites face major obstacles in their battle to survive and thrive, especially when it comes to generating revenues and profits. While local online ad dollars are growing fast-up 26\% in 2010 from the previous year and expected to reach $\$ 35$ billion by 2014 - competition is also increasing. The growth in spending has attracted both new and traditional media to the hyper-local market trying to capture some of these ad dollars (Schonfeld, 2010).

In fact, there is already fierce competition between the big players such as Facebook, Yelp, Craigslist, Yahoo, Google and AOL's Patch,13 which enjoy greater scale of traffic and lower ad rates. It is no longer clear that simply building consumer traffic will translate into a profitable revenue stream. In this context, it may be no surprise that, although online community news "projects built on the grit and passion of a particular founder or corps of founders have created the most robust models for short- and long-term sustainability," they are "not a business yet." (Schaffer, 2010) Most of the founders are working for little pay or as volunteers. 
The story of the Long Beach Post, a community news site that has survived for four years, can teach valuable lessons about the typical obstacles that entrepreneurs running these ventures face, what it takes to build a sustainable revenue model and what can be learned from the best practices of others trying to develop a sustainable business.

When Shaun Lumachi and Robert Garcia launched their community news website in 2006, they did not realize they were early pioneers in a growing national phenomenon. It all started with an email Lumachi received from Garcia:

"Hey man, I have a crazy idea. Let's talk."

"What's the idea?"

"Not over email. Call me."

"Can't talk. Just tell me over email."

"Let's start a newspaper."

With a couple of hundred dollars each, they launched the Long Beach Post, an online local news website (LBPost.com) to serve the coastal community of Long Beach, in Southern California. Home to nearly a half million residents, this suburb of Los Angeles is known for tourist attractions such as the Queen Mary, the Aquarium of the Pacific and the annual Grand Prix race through its city streets. Long Beach has a long and rich history of citizen involvement and community activism. And it was here where both Shaun Lumachi and Robert Garcia had decided to live.

Over the course of the next three years, they would ride a roller coaster of business highs and lows, trying different approaches to selling advertising and delivering local news. By fall 2009, the Long Beach Post was still alive, having grown steadily in traffic and impact, but as a business, the Post was not doing well. It had lost more than $\$ 100,000$, and there was no more cash to cover the losses. The business had a full-time managing editor, had implemented an impressive technology and had brought in an investor.

Traffic had improved to about 63,000 unique visitors and 106,000 monthly visits by January 2010, but that included its separate sports website. Most disturbingly, perhaps, the revenues were not keeping pace with the traffic improvements.

The Long Beach Post faced an uncertain future. How would it survive long term? Instead of $\$ 25,000$ a month - the original revenue goal - receipts ranged from $\$ 3,000$ to $\$ 5,000$ a month. That was a significant improvement from $\$ 1,000$ per month the first year, but the business continued to lose money or, in some months, barely break even. Readership was still growing but the investor's cash was long gone. After 


\subsection{The launch of Long Beach Post}

It was 2006. Lumachi, an intense young man, mature beyond his then 28 years of age, had graduated from California State University, Sacramento, where he had served as president of the California State Students Association-essentially student body president of the whole California State University system. There, he had befriended Robert Garcia, 29, who was president of the Associated Students at Cal State Long Beach. They shared an interest in politics and public policy, news and information, technology and community activism. Indeed, to this day, Lumachi sits on nine nonprofit boards in the city and tries to be a local leader "who serves his community through advocacy and the development of relationships." 14 And Garcia is an elected City Council member.

By the time of that spontaneous email, Garcia had finished his master's in communication at the University of Southern California and was working for the vice mayor of Long Beach, Frank Colonna. Lumachi had moved to Long Beach in 2002 to work for the local Chamber of Commerce and was starting his own consulting firm. They both worked for Colonna when he ran for mayor in 2006. Garcia ran the campaign and Lumachi was in charge of the campaign website. They would translate those roles (editorial and technology) to the new project.

The two entrepreneurs had a very straightforward and ambitious goal in mind: They wanted to "revolutionize and redefine" local media in Long Beach. They knew the world of journalism was changing dramatically and rapidly. It was unclear whether print newspapers would survive the changes in both technology and reader habits.

As Lumachi explained years later in a speech to a community group:

Nothing could be more inaccurate than to say that news is dying. It is changing, drastically. It is evolving, and it is up for grabs. Nowhere is that more apparent than right here in Long Beach, with a 100-year-old print newspaper, a slew of weeklies, several magazines and dozens of websites coming into the picture. ${ }^{15}$

Lumachi and Garcia did not fit the typical mold. They were not practicing journalists, but they had an idea, a passion for journalism and a strong commitment to make their enterprise work. Most of all, they loved their community of Long Beach-which Garcia thought was underserved by the Los Angeles-centric media 
outlets - and wanted to serve it and its residents. ${ }^{16}$

Long Beach is situated in a complex, robust and fragmented media market, part of the Los Angeles television and radio designated market area (DMA) - the second largest in the country - with seven VHF stations and nearly 100 over-the-air radio stations. It is the 38th largest city in the United States and the fifth largest in California. Smack in the middle of the circulation territory of the long dominant Los Angeles Times, Long Beach itself has a daily newspaper, the Long Beach PressTelegram, owned by Dean Singleton's Media News Group-once part of the defunct Knight-Ridder newspaper chain and today essentially merged with The Daily Breeze from nearby Torrance. In 2008, the two dailies combined "their Internet, copy editing and pagination operations in response to sagging ad revenue." (2 Southland newspapers to reduce, 2010)

"The Long Beach media scene is a lot like the city itself, incredibly diverse,"17 notes Ryan ZumMallen, managing editor of Long Beach Post. The city has several weekly newspapers, two local magazines and a variety of online special interest and community news websites - not exactly the kind of place you would want to start a media empire if you were worried about competition.

At first Garcia and Lumachi did not set out to build a profitable business. Their focus was on community service. They wanted to create an archive of community information, a place where community leaders and thinkers could gather,communicate and participate. Garcia hoped that the site "could be a chronicle of the city that will live on forever." But as early as three or four months after the launch, they realized that if this "community service" was to survive long term, it also had to be a viable business. "Reality set in," Lumachi recalls, thinking back to when he realized that "we [were] not creating a community service anymore, we [were] creating a business. And a business takes money and we [had] to figure out how to make that happen."

Lumachi and Garcia did not let the competitive landscape stand in the way of their vision. They sketched out a drawing of what the website might look like. It looked a little like Politico.com, a three-column, robust, Washington D.C.-based website they both admired. Quickly they realized the complex three-column site they envisioned was impossible to launch immediately. They decided to start anyway and "keep it simple" with a one-column spread and basic, not-very automated technology.

First, they needed content. They intended to rely on a mix of community contributors, unpaid professionals and paid freelancers, like many community news sites. Thev called these contributors their "nosters." Thev corralled several nossible 
experiment. They launched with about six contributors, and Garcia writing a political column.

Initially, Garcia was responsible for the editorial content and Lumachi worked through the night getting the technology to work. "I would wake up at 3:30 a.m. and build every single page by about 5 a.m., and then I'd send an email alert to a few thousand email addresses, which could take up to four hours," Lumachi recalls.

Knowing they could not keep up this pace, they wanted a robust technology platform that could incorporate written contributions easily and load them effortlessly. Working with a lone developer, they decided to create their own proprietary system rather than use an off-the shelf content management system. They designed it so that a writer sitting at a press conference could log into the system from his or her cell phone, write a story and have it up and available on the website within minutes. They also built the site so that it would be simple to load advertising as well. Once it was operational, the founders could spend time improving content and attracting advertisers rather than making the technology work. It was a key decision.

When they started, they had an open invitation on the home page for anyone to contribute, but they quickly learned that good content and reliable "posters" were hard to find. Lumachi was hoping for hundreds of "citizen journalists" to contribute local news stories but, similar to the experiences of other hyper-local community news sites, it turned out to be a challenge to get dedicated, regular contributors of quality content. Typically in community news sites, plenty of people say they want to write and get involved, but only a tiny percentage of those who express interest actually follow through. ${ }^{18}$

Instead, the founders of Long Beach Post turned to a professional-recent journalism graduate Ryan ZumMallen, who they hired as managing editor. He was soon turning out more than five stories a day, and his content was responsible for more than 85 percent of the site's readership.

When the site was finally launched, the team invited readers to join in "their great new media experiment." Their ambitions were not small, as they told readers: 
The Long Beach Post intends to revolutionize how you access community opinions and news. ... We hope to become the primary source of independent reporting and commentary on local, regional, statewide, national and international issues impacting Long Beach. ${ }^{19}$

\subsection{The business plan, the surprises, the obstacles}

Like most entrepreneurs, they had passion. They had a vision. They wanted to serve the community and fill a need. They did not, however, have much of a business plan, nor a proven business model. Their initial email correspondence that launched the project was in August 2006. A few months later, in February 2007, they launched the website, without a written business plan. In April, they realized they needed to articulate their goals. "So we launched in February and two months later we were like OK, what are we doing? We need to figure this out," says Lumachi.

They developed some specific goals - five milestones - they wanted to reach within three years, by Dec. 31, 2009:20

a) Traffic: 5,000 online visitors per day and 50,000 email addresses

b) Revenue: $\$ 25,000$ per month in gross advertising revenue

c) Staffing: A full-time content editor

d) Technology: Website automation

e) Financing: Sell or seek investors

They tackled their goals one by one. In 2007 they automated the website and developed their proprietary backend system. By September of that year, they had hired a full-time managing editor, allowing the founders to spend time on strategy and selling advertising. "Now that the system was automated [the managing editor] went in and did all the updating himself while Robert and I would sell advertising and focus on the big picture," Lumachi recalls.

They had more than 35 writers contribute during the course of three years, with 12 to 15 contributing at any one time. But they had to develop a more professional approach to their freelance writers, who demanded a lot of their time. "So, in the old days when we fired a poster, it was a month-long emotional process for Robert and me to figure out how we would do it because it was a personal relationship," explains Lumachi. "I remember when we first started we would get into heated debates [when] we knew we had to fire somebody. Today if they are not writing, they are gone." 
The site now has freelancers writing some specific stories or specials, for which they are paid $\$ 300$ per piece.

The site includes local news, commentary and sports, and also covers politics and election news. The team developed annual features, like the Long Beach "Person of the Year" and the city's "Ten Most Powerful" people. In 2010, the site launched an online database showing the salaries of city employees. Other popular features include "The Long Beach Election Center," which provides up-to-the-minute reports on local candidates, measures and propositions during the elections and "LBPostLive," which streams live events and webcasts live interviews so community members can ask questions of local leaders in real time. Readers "seem most interested in our political coverage, although our highest-traffic stories ever were breaking news such as coverage of the floods in January [2010] or [a] high school shooting," adds ZumMallen.

In 2008, Garcia left the business to run for City Council - a seat he won (ZumMalen, 2009). Although Garcia kept his ownership interest in the company, the potential for conflict of interest meant that he had to completely separate himself from the operations of the Long Beach Post. It was now up to Lumachi to make the business a success on his own.

\subsection{LBPostSports.com}

That same year, Lumachi made the decision to dramatically expand local sports coverage. He knew that high school and community sports had always been a popular mainstay of local newspapers and thought it would work on the web as well. He had developed a relationship with two leading local sports writers and launched LBPostSports.com.

We began providing game scores and analysis for all local sports-from high school basketball to collegiate tennis and everything in between," he explains. "LBPostSports.com managing editors Mike Guardabascio and J.J. Fiddler were hired to run our sports operation and the course of Long Beach sports coverage was immediately altered for the better.

The decision to pursue sports coverage instantly increased the quantity and quality of content produced by Long Beach Post and expanded the brand to reach an entirely new segment of Long Beach. ${ }^{21}$ Visitor traffic immediately improved and continued to grow. But would the sports coverage generate revenue and profit?

"Mike and I.I. iniected local snorts coverage with knowledoeable insight. inside sources that 
sports in Long Beach and were recognized by the Long Beach Century Club with the Keith Cordes Award for best promotion of the city through sports. They also hosted SportsNight, a weekly Internet podcast, and produced video reports of the major sports events - especially high school football games - that they distributed through YouTube. ${ }^{22}$ Unfortunately, revenue did not follow the spike in traffic and content.

According to internal Google Analytics for LBPost.com and LBPostSports.com, the traffic for both sites combined in the first six months of 2010 ranged from 45,000 to 65,000 unique visitors per month, and page views ranged from 112,000 to 170,000 per month. They also developed an important presence in social media to distribute their content and connect with the Long Beach community, reaching 1,000 Facebook fans and 1,390 Twitter followers by September 2010.

\subsection{Financing}

In early 2009, an investor committed $\$ 75,000$ to the Long Beach Post enterprise. The investment allowed for improvements, permitting Lumachi to focus heavily on content expansion and technology enhancements, but, at the same time, the extra cash gave him a false sense of comfort.

He did not feel the pressure of unpaid bills that might have focused his attention on growing revenue and achieving profitability. He assumed that by improving content and web design, visitor traffic would increase and revenue would follow.

He enhanced the "look and feel" of the site and invested in making the technology work better. By July 2009, as the investor's cash was running out, Lumachi faced a crisis. Financial reserves were being depleted and the future of the site was in question, even though he was in the middle of an already-paid-for redesign. Lumachi had built an inviting website that was attracting a growing cadre of readers; his technology worked flawlessly; there was plenty of solid news and information on the site. But he realized he had not paid enough attention to the revenue side of his business model.

Some of the responsibility rests upon my shoulders, he admits. I became very comfortable with the idea that that investment money was there and accessible and [the belief that the] next month will be better. And the following month will be better, and then the third month will be better. And then the following month will be better. And it never got better. ..." With the investor's cash running out, Lumachi had to focus on cost efficiencies and new ways to generate revenues. 


\subsection{Generating revenues}

The generation of advertising sales was the biggest challenge for the new startup. Initially, Lumachi sold the ads himself, although he clearly did not have time to devote to sales preparation, strategy and prospecting. Like many other community news sites, it was difficult to get advertisers to buy into the concept of a local community online news site as a place to market and attract new customers. Once they signed on, advertisers would frequently continue their commitment. That was the good news, but it was difficult to find new merchants to sign up in the first place.

In the first couple of years, two different salespeople sold with limited success. Lumachi was the first one, and then he hired a second salesperson part-time from December 2008 to July 2009. Initially she was paid on a commission only basis, making it difficult for her to earn a decent wage. "It was somewhat demoralizing, I think, to work hard [throughout] the course of the month and be paid a percentage of a few hundred dollars," recalls Lumachi.

At the same time, Long Beach Post had a very complex pricing structure. The rate card was complicated and difficult to explain, with 30 different price points and varied types of banners and ad positions for purchase. Prices ranged from as low as $\$ 150$ to as high as $\$ 750$. Lumachi was getting desperate. He picked up the phone and called an old childhood friend, Chris Foster, who was selling cemetery plots in Northern California. He figured if Foster could sell funeral services, he could sell advertising in the Long Beach Post.

Lumachi told his friend he would do his best to get his commissions to $\$ 2,000$ a month, that he would let him live in the office (a converted apartment above a retail store), and that his wife would make him dinner every night and even do his laundry, if he would move south and take over ad sales. With his friend Foster in place, Lumachi had a stable sales presence. He then streamlined the price points, and revenue started to grow. And it was not called advertising. The ads were positioned as "sponsorships."

Most advertising on newspaper or other content websites is based on what is called CPM, or cost per thousand impressions (i.e., how many times an ad is viewed by a reader)-unlike Google and some other new media outlets that rely heavily on CPC, cost per click, when advertisers pay when someone clicks on their advertisement. Advertisers use CPM to compare the cost effectiveness of advertising on different sites by using a universal pricing metric. 
result, many community news sites prefer not to charge by the users reached but by some other metric, such as a time commitment (e.g., your banner ad for a week on the home page). By characterizing the advertising as a sponsorship, the hope at Long Beach Post was that CPM would be deemphasized and the advertiser would feel like the ad was an investment in the community. The "sales pitch" became more about selling the Long Beach community, as well as the quality, loyalty and exclusivity of the audience.

Still, it was a hard slough for Foster. For many small to medium-sized businesses, the Internet was still relatively new as a marketing tool, although the percentage of them using new media is growing fast in the United States.

According to Foster, in a print advertisement, the advertiser has something real to hold, which helps demonstrate the impact. ${ }^{23}$

With an online ad, on the other hand, the impact has to come in the form of new customers in the door, and, oftentimes, it is difficult for a nightclub owner or a small local retailer, to know what drove a customer to try its products or services. For example, was it the banner ad on LBPost.com, word of mouth or the Yellow Pages that attracted a new customer? That's where the importance of a good sales effort came into play. Foster had to create relationships with the local businesses, helping them understand the value of online marketing, the impact of the Long Beach Post and the cost effectiveness of buying a sponsorship package. At the same time, a good salesperson has to do a lot of prospecting-cold calling businesspeople to try to get their attention.

Without that dedicated and unrelenting commitment and sales effort, it would be almost impossible to grow the revenue stream. ${ }^{24}$

"We were a startup and we needed somebody who was dedicated to the point where they would sacrifice their personal life," Lumachi says. "I was that person for the first two years, but considering everything else that I was doing, including my other company, [it was lucky I did not have] a heart attack. [F]inding that dedicated person who could do nothing but this and focus on it ... took us two years."

Lumachi was not alone in his quest for sales talent. One of the most common problems of startups generally, and community news websites in particular, is finding and retaining qualified, talented sales professionals. Turnover is high and

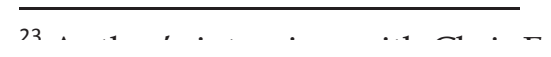


results are often mixed. Even managing editor ZumMallen recognizes the importance of innovative ways to generate revenue.

"It's a very competitive market and I think the challenge of covering a city as large as Long Beach consistently and accurately is a lot to ask of an operation as small as ours," he says. "It's a challenge that we certainly embrace but we have bitten off a lot to chew. Obviously it's also a difficult economic climate and it isn't easy to generate revenue online. These are the things we need to understand if we're going to survive, and so far we've done well, although there is a lot to learn."

Co-founder Garcia also recognizes the importance of advertising sales:

It is just as important as the content side. People overestimate how easy ad sales is. It is not easy. We are still figuring that out. We didn't have a plan for advertising. A little more investment on advertising sales would have helped us grow faster and bring stability quicker.

Nevertheless, Lumachi is positive about the future. "There are 35,000 businesses in Long Beach alone. There is enough advertising revenue to go around. It's whoever has the most value that can be offered and convince those advertisers to invest. The ones who get there first and can sustain the relationship the longest are the ones that will benefit." In late 2010, Lumachi made further adjustments to his advertising sales strategy. He put Foster on a commission-only payment scale, with no base salary. He hoped that Foster had built up enough existing business that he would earn a good minimum but have an incentive to grow the business even more. Lumachi reduced the number of ad positions on the site, raised rates and simplified pricing. Instead of requiring a 10page rate card to explain all the pricing and position options, a half page now does the job. And he considered adding a second salesperson.

The new system now has five fixed spaces on the right side of the site for rotating ads, but the same advertisers get visibility on the home page and with every single article. An extra space in the body of every article makes room for another sponsor's banner ad to appear. Also, they sell two banners at the homepage header. This increased visibility allowed the Long Beach Post to raise its ad rates. As the new ad rate card shows, they changed from "\$100 to $\$ 750$ a month" to "\$350 to $\$ 1,250$ a month." 
Equally important for distributing content and generating ad revenues is the Post's newsletter, or "e-alert," which Lumachi calls their "golden nugget." Newsletters go out twice a day and have two advertising spaces at the top and bottom. Long Beach Post has its own email service connected to the backend system in order to generate the ealerts easily, especially important when it comes to breaking news. The managing editor "just clicks on the stories he wants to send, presses a button and 20,000 people get that instantly."

\subsection{Managing costs}

Growing ad revenues was just one of the steps necessary to stabilize the business. The site still had too many expenses, forcing Lumachi to focus on the cost side of the business as well. The first step was to reconsider the sports strategy. Even though the separate sports site was generating thousands of visitors, winning awards and attracting attention, the overwhelming majority of advertising appeared on the main site, not the sports site. Even the modest investment of $\$ 750$ per month for each of the sports journalists was further draining the company's resources. Although the site was producing some of the best sports coverage in Long Beach, the strategy did not seem to make sense from a business perspective. It may have made sense from a long term investment perspective, but the long term wouldn't matter if Lumachi could not get the business to at least break even.

The challenge with sports was that it was the right idea at the wrong time in our growth," explains Lumachi. "We weren't ready for two [sports editors] of their capability and potential-they were overqualified and undercompensated and they overproduced. They produced 10 stories a day sometimes.

Lumachi estimated that the sports content was about 15 percent of the total content and attracted 25 percent of the readership, which was impressive, but drew little to no advertising revenue. One person, the managing editor of the main site, was producing 85 percent of the overall content, which was responsible for almost all of the advertising dollars. Something had to change.

One idea was for the sports editors to take LBPostSports over financially, sell their own advertising and be responsible for their own financial destiny. However, getting journalists to sell advertising turned out not to be a viable option-something that the producers of community news sites across the nation have learned the hard way. Lumachi considered a variety of options, including getting community contributors to be responsible for the content. But the separate sports site simply did not seem to work at this stage. 
costs of two writers. The twoyear investment in sports was over. "The sports site was part of our growing pains," Garcia notes. "I don't regret any decisions I have made, but in hindsight I could have moved quicker to cut costs," Lumachi adds.

\subsection{The future}

Lumachi and Long Beach Post have experienced many of the same challenges as thousands of entrepreneurial journalists who have attempted to build new community news business models. In the end, Lumachi acknowledges, business success and sustainability require the kind of editorial quality that attracts and retains readers, but also requires the proper balance between revenues and costs. By consolidating the sports site, the Long Beach Post's costs were now much more under control.

For the future, Lumachi has to focus on new and growing sources of revenue. He is open to and considering a variety of options and, fortunately, the operators of community news sites are beginning to share their success stories and lessons learned in forums and conferences. ${ }^{25}$

Other news sites, such as New West, have derived profits from running in-person, live events where participants pay a fee to attend (Westphal, 2009).

Some websites, like the Voice of San Diego, are incorporated as nonprofits and accept individual contributions and foundation support. The Long Beach Post is typical of scores of new community news ventures that have launched over the past few years. It is unclear whether this new business model will succeed and what it will take for those who survive to thrive.

ZumMallen is convinced that the basic concept is working:

Our own experience has taught me that there is a market for legitimate journalism because of the way our own traffic has spiked in the short amount of time that we've been around," he argues. "We've developed a trust and credibility in the community that places us right up there with the other legitimate news sources in the city. That's our bread and butter, so to speak, and it's how we'll continue to survive and grow in the future.

Legitimate journalism is needed more than ever as newspapers cut and slash their 
staffs, and I think readers recognize that and turn to sources without the big-name recognition but that are clearly committed to accuracy. The big complaint I get about online news sources is that it's difficult to tell which ones are trustworthy and which have an agenda, but in my experience it's easy to tell right off the bat when you're dealing with an experienced source that you can trust. I think our increasing numbers have shown that readers trust us to give them the truth.

There is no shortage of creative ideas at the Long Beach Post. The trick remains executing them well with limited staff and minimal investment. Lumachi is considering having the business produce revenue-generating events affiliated with its annual features, such as "Person of the Year" and "10 Most Powerful People.

We will do more events around them," he says. "We have two receptions during the year, one for Person of the Year and a reader appreciation reception, but [neither] of them is being exploited as a revenue stream.

He also is considering adding Google AdSense to the site as an additional revenue stream. Also, in 2009 the site launched UPost, an e-commerce hub where people can buy, sell, rent and shop locally. It did not bring the revenues he hoped for, but Lumachi explains that was mainly because they did not promote it. Partnerships are another potential source of new business.

Lumachi's overtures to the local newspaper and other local news sites have so far not been positively received. He fears that there is still too much focus on competition, rather than cooperation, among other local websites and print outlets. But he remains hopeful.

He has reason to be. Very few community news websites have already survived for four years. As one of the early ones that is still around, Long Beach Post's founders can be optimistic about the future of their enterprise. Their tenacity and commitment have so far paid off-if not yet in financial success, at least in the spirit of their original intent: community service.

"It is an absolute success," Garcia says. "The Post is one of the most read, most respected and talked about publications in the city. It has been a massive success from a community-service point of view. From a business perspective, it is still finding its way. It doesn't really make a profit, but it is for the most part self-sustaining. ... The Long Beach Post is here to stay."

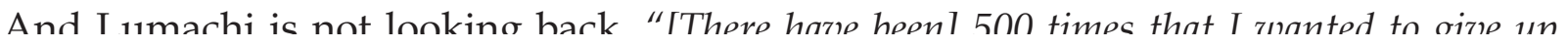




\section{REFERENCIAS}

Aris, A. \& Bughin, J. (2009). Managing media companies. Harnessing creative value ( $2^{\mathrm{a}}$ ed.). Chichester: Wiley.

Anderson, Ch. (2006). The Long Tail. New York:Hyperion.

Küng, L. (2008). Strategic Management in the Media: Theory to Practice. Londres: Sage.

Picard, R. (2010). Value creation and the future of news organizations. Lisbo: .Formalpress.

Kaye, J. \& Quinn, S. (2010). Funding journalism in the digital age. Nueva York: Peter Lang.

Anderson, C.W. et al. (2011). Shaping 21st Century Journalism. Leveraging a "Teaching Hospital Model" in Journalism Education. Washington: New America Foundation. (pendiente de publicación)

Grueskin, B.; Seave, A. \& Graves, L. (2011). The Story So Far: What We Know About the Business of Digital Journalism. Columbia Journalism School / Tow Center for Digital Journalism. Recuperado el 24 de noviembre de 2010, de http:// bit.ly/kSgx56

Mcclellan, M. (2010). Community news sites survey, part 1-4. Reynolds Journalism Institute. Recuperado el 24 de noviembre de 2010, de http://www.riionline.org/news/part-1-bloggers- no-more.

Kelley, D.; Bosma, N. \& Amorós, J. E. (2011). Global Entrepreneurship Monitor. 2010 Global Report: Global Entrepreneurship Monitor. Recuperado el 21 de noviembre de 2010, de http://bit.ly/qH4cBU.

Pew project for excellence in journalism (2010). The State of the News

Media 2010. Recuperado el 24 de noviembre de 2010, de http://www.stateofthemedia.org/2010/online_economics.php

Schaffer, J. (2010). New Voices: What Works, Lessons From Funding Five Years of Community News Startups. Knight Foundation. Recuperado el 2 de noviembre de 2010, de http://www.kcnn.org/nv_whatworks/pdf/.

Waldman, S. (2011). The information needs of communities. Federal Communications 
Garvin, D. A. (2003). Making the Case. Professional education for the world of practice. Harvard Magazine, 106 (1): 56-65.

Küng, L. (2007). Does Media Management Matter? Establishing the Scope, Rationale, and Future Research Agenda for the Discipline. Journal of Media Business Studies, 4 (1): 21-39.

Oguntoyinbo, L. (2010, Julio 29). Journalism Education Undergoes Academic Discipline Makeover. Diverse Issues in Higher Education. Recuperado el 24 de noviembre de 2010, de http:/ / diverseeducation.com/article/13989/

Shane, S. \& Venkataraman, S. (2000). The promise of entrepreneurship as a field of research. Academy of Management Review, 26(1): 217-226.

Westphal, D. (2009, February, 29). Recession? Local news sites are hanging tough. Online Journalism Review. Recuperado el 24 de noviembre de 2010, de http://bit.ly/Pq0iR.

Anónimo (2008, March 4). 2 Southland newspapers to reduce, combine staffs. Los Angeles Times. Recuperado el 2 de marzo de 2011, de http:/ / lat.ms / q5u5Pt.

Benkoil, D. (2010, Septiembre 3). Business, Entrepreneurial Skills Come to Journalism School. Mediashift. Recuperado el 24 de noviembre de 2010, de http://to.pbs.org/d0W6s1.

Efrati, A. (2010, August 19). Google vs. Facebook on Places. Wall Street Journal. Recuperado el 24 de noviembre de 2010, de http:/ / on.wsj.com/9joO1g.

Efrati, A. (2010, October 27). Google Plays Up Local Advertising, Business

Insider. Business Insider. Recuperado el 2 de noviembre de 2010, de http://read.bi/pUTCZD.

GLASER, Mark (2008, January 30). In Digital Age, Journalism Students Need Business, Entrepreneurial Skills. Mediashift. Recuperado el 20 de noviembre de 2010, de http:/ / to.pbs.org/4xdIix.

Jarvis, J. (2010, Enero 11). Teaching entrepreneurial journalism. Buzzmachine. Recuperado el 24 de noviembre de 2011, de http:/ / bit.ly/7VaF6Y.

Mcfadden, J. (2009, Enero 8). Entrepreneurial Journalism Call [notas de la videoconferencil. Recuperado el 2 de noviembre de 2010, de http:/ / bit.ly/oivhyb 
Slattery, J. (2011, Abril 24). A funeral for newspapers: Separating advertising and editorial. TheMediabriefing. Recuperado el 2 de noviembre de 2011, de $\underline{\text { http://bit.ly/g5jJev }}$

Switzer, C. (2011, March 2). Community Funds Are Offered New Ways to Measure Health of News Coverage in Their Cites and Towns. The Chronicle of Philantropy. Recuperado el 2 de noviembre de 2011, de http:/ / bit.ly / AvynvR

Tartakoff, J. (2010, August 26). Yahoo Revs Up Its Local Content Efforts. Paidcontent. Recuperado el 2 de noviembre de 2010, de http://bit.ly/oQNHkb.

Williams, L. (2010, October 19). The End of Journalism as 'Outsider Art. Knight Digital Media Center. Recuperado el 2 de noviembre de 2010, de http://bit.ly/cBJPag.

Zummalen, R. (2009, April 8). Garcia Wins First District Election For City Council. Long Beach Post. Recuperado el 2 de noviembre de 2010, de http://www.lbpost.com/ryan/2283.

Zummalen, R. (2010, February 8). LBPOST.com at Three Years. Long Beach Post. Recuperado el 23 de noviembre de 2010, de http://www.lbpost.com/ryan/8265.

Annenberg school of communication (2009, December 4) Entrepreneurship and the Community Web. [Grabación de conferencia vídeo]. Recuperado el 23 de noviembre de 2010, de http:// bit.ly/1VlOct.

Reynolds Journalism Institute (2010, September). Block by Block: Community News Summit 2010. [Grabación de conferencia vídeo]. Recuperado el 13 de noviembre de 2010, de http://bit.ly/rt9Oni.

The Paley Center For Media (2010). Education of the Entrepreneurial Journalist. [Grabación de conferencia vídeo]. Recuperado el 23 de noviembre de 2010, de http://www.paleycenter.org/carnegie- entepreneurial-journalism/. 


\section{María José Vázquez-Schaich}

María José Vázquez es licenciada en Comunicación por la Universidad de Montevideo en Uruguay y doctoranda en el departamento de Empresa Informativa de la Facultad de Comunicación de la Universidad de Navarra. En 2010 fue investigadora asociada en el Center of Communication, Leadership and Policy de la Annenberg School of Communication de la Universidad de Southern California 